\title{
AN EXPLORATION OF INDIVIDUAL EXPERIENCES OF CONSTANT ORGANISATIONAL CHANGE
}

\author{
K WILLIAMS \\ A CRAFFORD \\ L FOURIE \\ Programme in Industrial Psychology \\ Department of Human Resource Management \\ Rand Afrikaans University
}

\begin{abstract}
Ongoing change is an inevitable part of the current organisational context. Change management practices are often cited as a reason for resistance to change, and as a cause of stress for individuals during change interventions. A qualitative study was undertaken in a technical division of a large South African organisation to explore the individual experiences of employees in the face of constant organisational change. Grounded theory analysis confirmed that constant organisational change and the related change management practices were indeed a source of unpleasant individual experience for employees at the time. Yet, no serious long-term effects of stress were evident. It is suggested that Strümpfer's (1983-2000) work on salutogenesis and fortigenesis may be useful in explaining the outcome. Further research incorporating larger sample sizes and multiple triangulation methods in the data gathering process is recommended.
\end{abstract}

\section{OPSOMMING}

Kontinue verandering is 'n onvermydelike deel van die huidige organisasiekonteks. Veranderingsbestuurspraktyke word gereeld geopper as ' $n$ rede vir die weerstand teen verandering asook die oorsaak van spanning by individue tydens veranderingsintervensies. ' $n$ Kwalitatiewe studie in die tegniese divisie van 'n groot Suid-Afrikaanse maatskappy is onderneem om die individuele ervaring van werknemers tydens konstante organisasieverandering te ondersoek. 'n Begronde teorie-ontleding het aangetoon dat konstante organisasieverandering en die gepaardgaande veranderingsbestuurspraktyke inderdaad ' $n$ bron van onaangename ervaring vir werknemers is. Desnieteenstaande was ernstige langtermyn gevolge van spanning nie waarneembaar nie. Dit word aangevoer dat Strümpfer (1983-2000) se werk oor salutogenese en fortigenese nuttig mag wees in die verklaring van die bevindings. Verdere navorsing wat groter steekproefgroottes en intermetodiese kruisvalidering tydens die data-insamelingsproses insluit, word voorgestel.

"The 20th century bore witness to some of the most dramatic changes humanity has ever undergone. The automobile changed the world; the airplane made it possible to have breakfast in Paris and lunch in New York City; radio and television delivered news and entertainment from all parts of the world in real time. Nuclear energy was used for good and evil. But the changes brought about by the internet may turn out to be the most dramatic of them all" (Sifonis, 2000, p. viii).

This statement reflects some of the changes that have become a pervasive part of our lives as human beings and have impacted on all contexts in which we function, be they technological, economic, social or political (Siegal et al., 1996). In addition to the speed with which change occurs, it can also no longer be viewed as a once off event in response to a particular problem but as a continuous and open-ended process in response to turbulent and chaotic times (Burnes, 1997; Dunphy \& Stace, 1993; Veldsman, 1997). In response to this, organisations have had to develop the core competence of successfully managing change. Organisations in South Africa are no exception in this respect (Veldsman, 1997). Slabbert and de Villiers (1998) emphasised that the context in South Africa had changed fundamentally as the country is no longer isolated because of the previous political ideology. South African organisations now have to rapidly find solutions to their problems in the context of globalisation.

In responding to the necessity for transformation, Veldsman (1997) has proposed the concept of 'change management logic', which is the way the organisation believes, either implicitly or explicitly, that change should be managed. The change management logic is composed of different 'interdependent levels of decreasing visibility, and increasing depth' (Veldsman, 1997, p. 1). He identified three levels of logic, the deeper level forming the context for an earlier level. Level 1 comprises a set of change management practices (or activities) used to mediate the changing reality of the organisation. This level is the most visible and concrete and encompasses the 'doing' part of the logic. Level 2 is reasonably visible but less concrete and entails the change management approach (or model) used to synthesize, organise and direct the overall change intervention. A set of change management practices (Level 1) are selected, sequenced and applied within the context of the change approach adopted. Level 3, the most invisible and abstract aspect of change, is the change management paradigm that acts as the fundamental frame of reference (or interpretative scheme) when viewing change and its management. Veldsman (1997) suggested that it is critically important to know the change management paradigm that an organisation operates from as this determines both the approach and practices used in the change process.

In similar vein Beer and Eisenstadt (1996) suggested that even when managers perceive the necessity for a new strategic direction, their inability to implement the strategy might be their downfall. They identified three principles that should characterise any effective change process. Firstly, the change process should be systemic with a 'fit' between the 'hard' elements of technology, strategy and structure and the 'soft' elements of skills, values and leadership. Secondly, the change process should be characterised by open discussion of barriers to the effective implementation of strategy. Politics and defensive behaviours should not impede the discussion of threatening or embarrassing topics. Thirdly, the change process should develop a partnership among all stakeholders as the people at the top of the hierarchy are not always in the best position to know what processes are best for those who are responsible for implementing and using the new systems (Beer \& Eisenstadt, 1996).

\section{Change management processes}

Bearing in mind the preceding discussion, there are numerous examples of management practices in the workplace that would 
accompany change, for example: (a) rethinking strategy (Hamel \& Prahalad, 1989; Lascaris \& Lipkin, 1993); (b) the way in which the strategy is operationalised by using different economic models (Arthur, 1996); (c) introducing technology to support productivity and performance (Winslow \& Brammer, 1994); (d) using knowledge workers (Shukla, 1997); (e) new organisational structures which are dependent on the labour market (Horwitz, 1995; Horwitz \& Franklin, 1996; Simmons, 1996); (f) different ways of managing human resources (Armstrong \& Murlis, 1997; Hall \& Mirvis, 1995; Mabaso, 1998; Marshall, 1995; McLagan \& Nel, 1996; Teke, 1997); (g) and the expectations from leaders (Birkin, 1998; Manning, 1997). According to Kotter (1995) only a few change initiatives are ever regarded as truly successful: some can be described as utter failures whilst others can be described as only moderately successful to essentially unsuccessful.

Much has been written on how to ensure that these change management practices are successful. In a review of work by 13 authors on barriers to change, Applebee (2000) concluded that the following can be done to avoid the ten most common barriers to effective change: (a) take note of the impact of corporate politics; (b) ensure sufficient managerial, financial and systems support; (c) balance the short term and the long term view; (d) obtain the trust and "buy in" from the staff, ensuring that their psychological contracts with the firm are revalidated; (e) ensure the commitment of all staff, particularly leadership at all levels; (f) leaders must "walk the talk"; (g) beware of the legacy of the past as change is a threat to the firm's existing culture, systems and procedures that are rooted in the past; (h) consider top management "groupthink", or conversely fragmentation, as threats to the change process; (i) manage implementation systematically, with the use of a degree of urgency and ( $\mathrm{j}$ ) consider the change in a larger systemic context.

While it can be argued that change is necessary to remain competitive, it may sometimes be forced on employees who are expected to adjust without protest. According to McHugh (1997) management in organisations thus stands accused of implementing change, which they believe will benefit the organisation, without consideration for the effect that it will have on employees. Mack, Nelson and Quick (1998) emphasised the importance of considering individuals during organisational change. They argued that although the changes are generally essential and overdue, the potential cost to the individual and the company in terms of medical expenses, lost productivity and lowered motivation and morale cannot be ignored. Furthermore, the costs can be directly attributed to the adverse conditions and stress encountered by individuals during organisational change.

\section{Stress responses to change}

Quick, Quick, Nelson and Hurrell (1997) noted that while stress and strain are features of organisational life, these concepts tend to be ambiguously defined. Despite the ambiguity stress and strain remain a matter of serious concern to medical and organisational professionals. The concern is for two reasons: one being economic, as mismanaged stress can cost organisations billions of rands every year in lost productivity and health care costs; the other being humanitarian, as it is not desirable to overstress individuals. Leong, Furnham and Cooper (1996) stated that stress resulting from work is a major problem, both for individuals within an organisation and for organisations themselves. For this reason, it is argued that it is in the organisation's best interest to intervene and minimise the amount of stress that is caused by continuous organisational change in particular (Mack et al., 1998). However, despite extensive research and theory generation on the topic of stress in general, the impact of organisational change on individuals, and especially the impact of continuous change, has received very little attention (Mack et al., 1998).

Sarason and Johnson (1979) conducted one of the first studies on the relationship between changes experienced within the personal lives and work lives of individuals and the impact of these changes on job satisfaction. Subsequent research has considered various aspects of the change-stress relationship. Examples of such studies are Callan (1993) who examined individual strategies for coping with organisational change. Terry and Callan (1997) attempted to predict employee adjustment to organisational change using a model of four components - event characteristics, situational appraisals, coping strategies and personal resources. Their model received some support, and provided insight into developing stress management programs. Huuhtanen (1992) examined stress associated with the introduction of new computer systems in banks. Scheck, Kinicki and Davy (1997) examined mediators of the stress-change relationship but included the dimension of individual appraisal of stressors. They concluded that more powerful explanations of the complex dynamics between stress and coping phenomena are required.

Within the South African context a limited number of studies on work-related stress have been undertaken. Pretorius (1992) examined the role of problem solving skills in the relationship of stress to distress in an educational setting, and also the moderators of the stress-burnout relationship within this context (1993). Strümpfer (1989) found that South African managers experience similar levels of stress to their international counterparts on a variety of job demands, role stressors and social support factors. Since most of the published research focussed on stress in the work environments of teachers, nurses and the police force, it seemed desirable to also conduct research among other populations.

Very few studies on stress and organisational change have adopted a qualitative approach to the research. Sparrius (1992) successfully used the approach to identify occupational stressors among ambulance and rescue service workers. Isabella (1990) used the approach to examine how managers construe essential organisational events. The results revealed that the interpretation of key events evolve through a series of stages. In particular, the results suggested new ways of dealing with resistance to change, and managing the change process more effectively. Schabracq and Cooper (1998) recommended that alternative descriptive approaches to the study of stress should be used to supplement the more traditional methods.

McHugh (1997) adopted a mix of qualitative and quantitative methods to examine the impact of various organisational changes on employees in a Swedish company that had undergone several years of organisational change, aimed at increasing accountability, efficiency and effectiveness. She found that the top ten concerns of the employees related to the way in which their work had changed, i.e. increased workload and work complexity with decreased resources: time, finances and staff. The cultural audit revealed that job demands increased and that the support that employees received from their colleagues was not ideal, thus contributing to the experience of stress. In considering psychological well-being, the participants' scores were average, with anxiety scores generally being higher than depression scores. The results of the study were used to motivate the need for preventative measures in implementing organisational change (McHugh, 1997). According to Armenakis and Bedeian (1999), the study provided support for what many researchers would consider to be an obvious conclusion, namely that the climate of constant change which characterised the Swedish social insurance system was a major concern and source of stress for many employees, although probably not unique to those organisations.

Kets de Vries and Balazs (1997) concluded at the end of another qualitative study that insufficient attention is often given to the cognitive and emotional aspects of organisational change on the individual, leaving many important questions about psychological processes unanswered. In a series of interviews with various players in the change process, they uncovered valuable insights into the way in which change may result in a 
number of poorly understood emotions. These emotions included anger, depression, fear, guilt, risk aversion, distrust, vulnerability, powerlessness, feelings of loss of control, loss of morale and motivation. They further identified a process of mourning in which people seemed disoriented, felt as though they didn't fit in and wondered what the future would be like. Employees also experienced periods of self-reproach and sadness, as well as a preoccupation with the past. Other aspects that were raised as issues of concern included the uncertainty caused by the threat of further downsizing, the sharp increase in workload, and longer working hours caused by staff reductions.

In another study Jex, Adams, Elacqua and Lux (1997) compared the results obtained from scale measures of stress with scores from a critical incident method. They concluded that the qualitative research technique was indeed a viable method for studying work related stressors. One of the criticisms against the use of the scale measures was that these provided little detail of how stressors were manifested at the behavioural level. A qualitative method tended to not only provide information regarding the intensity and frequency of stressors, but also important information as to the meaning of the stressors. Whilst each method seems to have its place in research, the aforementioned authors specifically recommended the use of multiple methods to study workplace stress.

\section{Purpose of the study}

For the purpose of this study, therefore, a qualitative approach was adopted and emphasis was specifically placed on the individual experiences of employees in the context of ongoing or constant organisational change. The proposed study was aimed at exploring the effects of multiple organisational changes on individuals, and the way in which change practices in particular (Level 1 of the change management logic) were experienced. Attention was further directed at the individuals' reaction to the possible stresses inherent to the process, and in particular the ability to cope with the afore-mentioned. It was believed that the use of a qualitative research methodology would facilitate a better understanding of the personal experience of different individuals with the ultimate aim of adapting change management practices accordingly.

\section{RESEARCH DESIGN}

To explore the effects of multiple workplace changes (and particularly the way in which these changes were managed) on employees, a qualitative study within a large organisation, known for a series of major organisational changes over time, was undertaken. Although the preliminary literature review dealt with many of the realities of ongoing organisational change and the possible effects of these on employees, a grounded theory approach was followed and limited theoretical assumptions were adopted as a baseline.

\section{The context}

The study was conducted in the technical division of a large multinational, traditionally South African-based company, which had relocated its Head Office to London in 1999. In July 1998 a strategic business unit with a technical focus was formed. One of the main challenges facing the new technical business unit was to diversify its client base. While continuing to provide services to its traditional in-house clients on a contractual basis, it was at liberty to offer its services to an international customer base in the open market. In the new structure, there was a strong emphasis on business development, proposals, tendering and marketing, and a move away from a cost centre to a profit-generating arm of the holding company (Company Annual Report, 1998).

However, in January 2000, a new Technical Director was appointed who insisted on consulting clients in re-determining a strategy for the business unit. The outcome of the review was that clients wanted the business unit to focus solely on providing a technical service to the internal client base (as opposed to also operating in an open market), albeit at a competitive price. External clients were henceforth not to be included in the core focus of the business unit. This development essentially represented a 180-degree turn from the mandate given in July 1998, implying not gradual and incremental, but truly transformational change. Among many major organisational changes, it was envisaged that the workforce would be split into "core" and "non-core" employees. Over a period of time, the "non-core" employees would change their working relationship with the company and no longer be regarded as 'permanent employees'.

As might have been expected, individuals were wary of the change. An in-house Employee Assistance Programme counsellor confirmed this sentiment. An observation by the researcher indicated that the change management process up to that point might not have been well organised and focussed and in some instances it could well be argued that elements within the organisation had become dysfunctional.

\section{Selection of research participants}

Maxwell's (1996) "purposeful or criterion-referenced sampling" technique was used to intentionally select situations, people or events which would provide important information that could not be obtained by using other more statistically appropriate sampling techniques. It was decided that staff permanently employed in engineering or technical positions in the Paterson grade DU would be targeted. These employees were specifically selected to ensure focus on the core business of the division, i.e. engineering and technical consulting to internal clients. The reason for selection at the particular organisational level was motivated by the reality that these employees represented a layer of employees just below senior management: the latter usually being the decision makers and implementers of the changes and the former mostly at the receiving end of the changes. Being positioned between senior management and lower level staff, these employees were expected to be actively involved in the changes from an operational and instrumental point of view.

At the time the research was conducted, the total permanent staff complement of the division was 256 . The target population was set at 25 and, unable to stratify the population further, a list of surnames was compiled. Every third person was asked to participate, rendering nine participants in all. All the participants were white males, with an average age of 39 years within a range of 32 to 59 years. The average length of service with the company was eight years within a range of four months to 20 years. Four of the participants had only ever worked for the company being studied, although three of them had worked in different divisions of the company. The other five had also worked for companies other than the one in the study. All of the nine participants had been part of various organisational changes, and mentioned these in various degrees of detail during the subsequent interviews. Most of them, however, chose to focus on the most recent change the company had been going through, probably because it was still unfolding at the time of the interviews and, therefore, uppermost in their minds. It is also important to note that all the interviewees were "survivors" of the most recent change initiative.

\section{Data collection methods}

Each participant was contacted telephonically, given a brief outline of the proposed research, and requested to participate. An appointment for the interview was scheduled a few days later. None of the participants were aware of who the other participants were, and confidentiality was assured. Interviews were scheduled with each of the nine participants over a two-week period, and only one interview was conducted with each participant. 
The interviews took place in a quiet meeting room or in the participant's office during normal working hours. The interviews lasted between 30 minutes and two and a half hours. The interviews were unstructured, with a single initial question being posed: "Tell me about your experience of constant organisational change". Thereafter, only reflection was used to encourage further discussion. Questioning for clarification was used, but deliberately kept to a minimum. This approach was followed to manage the threats to validity as discussed in the next section. All interviews were audiotaped with the permission of the participants and it was agreed that they could request that the tape be switched off at any point during the interview if they felt uncomfortable with what they were about to say being on tape. Two participants exercised this option to a limited degree.

Prior to the research, two pilot interviews were conducted primarily to ensure that the question would stimulate enough discussion of the topic, and to allow for physical aspects like the quality of the recording to be monitored. Observation notes were made throughout and after the interviews, and tapes were personally transcribed verbatim. This was done with the intention of facilitating the analysis process and to ensure that the researcher did not subjectively influence the results unduly.

\section{Managing threats to validity}

Bryman (1989) correctly stated that social research requires certain trade-offs, as it is almost impossible to avoid all the threats to validity inherent to the studying of social phenomena. He argued that the aim should rather be to limit the disadvantages and maximise the advantages of the research choices made. In this vein, special attention was given to the requirement for objectivity, to the threat of reactivity, to the need for reliability, and to need for validity.

Objectivity is often raised as a concern in qualitative research. Because the researcher is so intimately part of the process it is difficult to expect a research stance totally void of any degree of subjectivity. Smaling (1989), however, offered a workable approach, which was adopted for this study. The approach is referred to as "Münchhausen Objectivity" which implies the following assumptions: (a) "allowing the object to speak" thereby recognising the point of view of the object of the research; (b) recognising that the experience of the researcher is not necessarily a threat to objectivity but rather an element of learned subjectivity which may enhance the process; and (c) viewing objectivity as a state of mind or an attitude, which requires active involvement and interest on the part of the researcher. These guidelines were adhered to throughout and the researcher actively withheld undue participation in the data gathering process.

Reactivity was further recognised as a possible threat, yet inescapable part of the interviewing, which according to Maxwell (1996), can never be eliminated entirely. While the influence of reactivity could not be ruled out completely, it was constantly considered as a threat throughout the interviewing process. Deliberate attempts were made to limit personal biases and to remain within the framework of the question posed. Reactivity was further addressed by asking a single research question, and by only concentrating on and listening to the responses from the participants.

Reliability, according to Smaling (1992), may be enhanced by using one or more methods of triangulation. In this study a process of peer reviewing was used to increase inter-rater reliability. During the data analysis phase, a senior colleague was co-opted to assist in the checking of the data and the resultant categorisation thereof. To ensure the integrity of the data obtained the 'mechanisation of registration' technique was employed, i.e. all interviews were audiotaped and transcribed verbatim. This was done with the prior permission of each participant (Smaling, 1992, p. 82). Reliability was further bolstered by later giving each interviewee the opportunity to read and comment on the transcript. Each participant confirmed that the transcript was an accurate record of his views and feelings at the time. To further ensure reliability, observation memos were compiled after each interview and notes were made on any observation during the interview process that could compromise the information obtained. These notes were considered throughout the process of data analysis. In reviewing the observation notes, one aspect that could possibly have been a threat to the reliability and validity of the data became apparent. The researcher noted that some respondents appeared not to have had complete trust in the process, possibly withholding sensitive information from the researcher. The fact that two participants had also asked for the audiotape to be switched off confirmed the notion that not everyone had complete faith in the confidentiality of the process.

A further threat might have been present as a result of the fact that all the participants were indeed "survivors" of the change initiatives. It is possible that a completely different set of responses would have been forthcoming from individuals who had fallen "victim" to the changes.

To ensure external reliability, and to facilitate replicability, the research process has been described in detail (Smaling, 1992).

\section{Data analysis}

A grounded theory approach was chosen as it provided for a thorough, open analysis of the data, particularly given the relatively large amount of unstructured data generated in the study (Easterby-Smith, Thorpe \& Lowe, 1991; Glaser \& Strauss, 1967). Codes were assigned to the data in the process of analysis from which more abstract categories and propositions were derived (Hussey \& Hussey, 1997; Pandit, 1996)

To achieve this, each line of data in each of the nine interviews was analysed and the main idea (open code) captured in the margin. In total 4071 lines of data were analysed (55 500 words). The comments were then grouped according to themes and an axial code assigned to each. The grouping process was repeated several times, and refined each time. A system of allocating coloured papers to different sets of data allowed crossreferencing to individual responses at any time, and eventually facilitated the formation of a matrix, which contained the various categories and the individual responses in each category. The matrix also contained the notes taken after each interview, and the biographical data of the respondents. At various stages the categories were discussed in detail with the research supervisors as well as a respected peer, further assisting in the process of refining and description of the categories.

\section{RESULTS}

The grounded theory analysis of the data yielded six distinct categories, namely: individual psyche, future prospects, systems and tools available to do the work, interaction with colleagues, the role of managers and their practices, and clients. Each is discussed in turn.

\section{Individual psyche}

The experience of constant organisational change seemed to manifest in direct effects on the individuals' psyche in two ways: firstly, it influenced their beliefs about change, and secondly, it impacted on their emotions and feelings. With regard to the respondents' beliefs about change, each participant seemed to have one overarching belief about change. Most of the responses linked to an overarching premise about change were either neutral or marginally positive in tone. For example:

'The effects of change are far reaching: we are not taught how to handle change as part of the school or university curriculum and our parents were not equipped to teach us as 
they had a different psychological contract at work; life is change; the organisation must change to be competitive; some things change without you even realising it; we forget some of the changes we have been through; change builds resilience, character, confidence, learning". Of particular interest were comments that indicated that previous change be it at an organisational or even personal level - somehow equips one to better deal with future change. The general feeling was that it helped to prepare one for future changes, that experiencing change in any aspect of your life (be it the birth of a child, divorce, the death of a spouse) is useful in preparing you for changes at work.

"Often, when you look back, the experience of change was not so bad after all; and: "you don't always remember all the changes".

With regard to emotions and feelings, the respondents reported a wide array of experience. Individuals typically expressed more than one emotion. Seven of the nine respondents experienced markedly negative emotions, comprising of the following:

Disruption, fear, anger, uncertainty, aimlessness, discomfort, fear, a sense of being ignored, loss of self-esteem, surprise at the suddenness of the changes, demotivation, loss of energy, stress, frustration, upset, loss of loyalty (though not necessarily a corresponding loss of responsibility), acceptance (in the sense of resignation only), powerlessness, and relief when realising that they would not be affected negatively.

\section{Future prospects}

Experiencing constant organisational change seemed to impact on individuals' beliefs about their future prospects in two areas: firstly, their future career opportunities, and secondly, their financial security. Five respondents saw both a possible negative and a positive impact on their careers, three expected a negative impact and one did not venture any views in this respect. Respondents often expressed the view that it was important to keep one's options open by exploring opportunities. Respondents were generally satisfied with their careers and chose not to move until a final outcome of the change process was announced. (On an interpretative level it was argued that this might be a feature of the respondents' occupational status as engineers). It is generally assumed that they have marketable skills and that they are probably able to find alternative employment with relative ease.)

Four respondents referred to their future financial prospects: one felt neutral, whereas the others felt negative, largely about the pension fund rules and how much they stood to lose, should they decide to resign rather than wait for retrenchment. In some respects they felt trapped by this situation. The other area of dissatisfaction mentioned was concerned with general company benefits. These were reportedly changed from time to time without ever having a truly positive impact on the individual: "technically managers do not lie about the benefits to us, but they are not one hundred percent truthful".

\section{Systems and tools available to do the work}

The main area of concern in this instance related to the fact that while certain aspects of the organisation had changed, the business systems in particular had not been adapted. This made interfacing with clients very difficult and frustrating, in that the engineering work became secondary to managing the business (accounting) system. Other frustrations were the document management system, which was perceived as not being user friendly, and the recent loss of people, which would result in the company not being able to fulfil its future objective of managing big projects - a concern about the sustainability of the business.

\section{Interaction with colleagues}

Interestingly, rather than note their own behaviours or feelings, respondents generally related how other people reacted or behaved at work/ in the team. They spoke about the loss of team spirit - "people become nervous and start to look out for themselves; sometimes conflict arise or may be exacerbated; people withdrew from the team or department and preferred to come to work, close their doors and avoid contact with their colleagues". People who were retrenched as a result of the organisational change no longer wanted or received farewell parties - "We seem to have become harder; what should have been joyous occasions, for example long service recognition functions and Christmas parties were sombre". People were described as "stressed, unhappy, angry, negative, bitter, isolated, insular, and tense".

\section{The role of managers and their practices}

The respondents raised a number of issues that are consistent with much of the literature on change management practices:

- the lack of any real participation in the change process

- the perception that the end result is known and that any participation is a farce

- that management are inconsistent and unfair in their practices

- that employees distrust management - it is difficult to know when managers are being truthful and this creates a credibility problem for the middle managers (participants) when dealing with their subordinates

- that organisational change is not well considered but rushed to meet artificial deadlines

- that the change is made more complex than it need be

- that financial results are not shared and therefore employees do not understand how their efforts impact the business; this results in speculation which is probably inaccurate

- managers shirk their role and responsibility in implementing changes by hiding behind vague statements from unknown shareholders.

\section{Clients}

The overriding issue here was that despite various changes within the company in the last few years, the ultimate deliverable to clients had remained unchanged. There were some concerns that the management's discussions with clients took place at the wrong level and that the people that the participants interacted with were not fully informed of the new business strategy. This made relationships with clients difficult and appeared to have a negative impact on their ability to secure work, which in turn caused concern for the participants because it affected the long-term viability of the business.

\section{DISCUSSION}

The study highlighted a number of learning points. Of particular value in the first place is the finding that people seem to show a great deal of resilience in the face of ongoing and sometimes confusing change. This may be as a result of intrinsic fortigenic strengths (Strümpfer, 1995) on the one hand, but also as a result of individuals' natural response cycle to change on the other hand: from initial shock to eventual acceptance. It is important to note, however, that acceptance in most cases could at best be described as resigned acceptance. The impression was not created that change had been fully internalised and that the subsequent involvement in the change was truly as a result of personal choice. This raises the question of employee commitment during organisational change processes. The subtle expressions of cynicism by the participants regarding change in general, but also about the perceived leaders of change, is a further point of concern when real commitment is required from employees to affect deep change with any degree of success. 
A second learning point has to do with the apparent value of previous change as a vehicle for equipping people to better deal with future change. Individuals seem to draw on their own and others' experiences to construct meaning and find solace in their own experiences. Participants highlighted their acceptance of the notion of change as an ongoing phenomenon and indeed viewed organisational change within the larger context of life in general. It has been mentioned earlier that all the participants had been through a series of organisational changes. However, no one indicated discernable cumulative effects as a result of these continuous changes. When previous changes were mentioned, it was mostly referred to in the sense of developing resilience and coping skills for current change.

A third important learning point refers to the nature and scope of the emotions experienced by individuals during organisational change processes. Concerning these emotional experiences several of the Kets de Vries and Balazs (1997) findings were replicated. These included the experience of emotions such as fear, powerlessness, disorientation (expressed as aimlessness), lack of motivation, loss of control over the situation, as well as uncertainty of the future. The seriousness and depth of the emotions mentioned during the interviews should not be understated. From a psychological point of view, the emotions mentioned included some of the most vital in terms of emotional well-being, for example: loss of self-esteem, feelings of helplessness, fear and anger. It is obvious that these feelings can hardly be dealt with at a superficial level through normal organisational change management processes with a generic focus. Appropriate psychological counselling and support would probably be required. The study also highlighted the importance that work seemingly plays in establishing a person's self-esteem: threats to a person's job appears to significantly impact a person's overall self-esteem.

However, other negative emotions (such as feeling ignored, or uncertain, or surprised) could possibly have been prevented through appropriate and timeous communication. Proper change management processes and communication strategies in particular, might have had great value in alleviating the unnecessary stresses and discomfort of employees as a result of them not being informed of changes possibly affecting them negatively, or otherwise.

A fourth area of particular importance highlighted aspects relating to participation. Whilst participation is often mentioned as a key requirement for successful organisational change (Applebee, 2000: McLagan \& Nel, 1996; 1997) participants cited a perceived lack of participation throughout the change efforts. They acknowledged that attempts towards participation were made but viewed these farcical, and simply an artificial attempt to comply with labour legislation. Participants perceived results to have been known prior to consultative processes and stated that managers were not always 100\% truthful in their dealings with employees.

A fifth learning point stressed the value of appropriate change management practices. Many participants indicated that good practice was not always adhered to. Winslow and Brammer (1994) and Applebee (2000) suggested that technology (or systems) to support productivity and performance should be available throughout the change process. However, participants felt that business systems in particular were lacking and that intended changes fell by the way because systems and processes had not been aligned accordingly. Applebee (2000) further mentioned the importance of maintaining a balance between the long and short-term view. Participants felt that the way in which the business had been structured in the short term often compromised the sustainability of the business in the long term.

Issues of trust and credibility featured as a further point of interest. Participants perceived the leaders of the change process to not always "walk the talk" as recommended by Applebee
(2000). They seemed to rather "shirk their responsibilities by hiding behind shareholders". Managers also seemed to be unable to systematically manage the change with a realistic sense of urgency. Participants indicated that managers often rushed the changes to meet artificial deadlines.

A seventh aspect of interest dealt with participants' loss of loyalty and a sense of demotivation. Whilst participants clearly indicated a loss of loyalty and demotivation it did not seem to necessarily affect their sense of responsibility towards their jobs. They felt that they still had an important professional role to play. What is of particular importance, however, is the apparent loss of synergy within teams. Participants indicated withdrawal, people no longer functioned as coherent teams, distrust developed, people became self-centred and insolate. If it is assumed that organisational change processes by their very nature require teams to work together, to find solutions and to implement changes the importance of successful team functioning should not be ignored. It is important to note that participants often referred to their experiences in interpersonal terms: themselves as being part of a larger context and ultimately connected to others. Losing a sense of belonging and the ability to create synergy through teams therefore has profound implications for managing change within organisations.

Probably the most insightful finding dealt with the issue of stress as a result of continuous change. It was expected that constant organisational change might lead to stress, and possibly also to cumulative effects of stress. Despite indications that every participant experienced a marked yet differing degree of stress, the impact did not appear to be as negative as one would have expected. This may be attributed to the fact that much of the literature on stress had its origin in the traditional pathogenic paradigm of psychology and medicine. The focus of this paradigm is finding the source of disease or illness with the aim of combating and preventing illness in the future. Attempting to adapt change management practices to reduce stress experienced by individuals during the change process would be an example of this approach.

However, there has been a shift of emphasis from the pathogenic paradigm and the focus on disease towards a fortigenic paradigm and an emphasis on the origins of health and strength (Strümpfer, 1990; 1995; 2000). Strümpfer outlined the development of the paradigm he now calls fortigenesis (Latin: fortis = strong, Greek: genesis = origins), through its emphasis on health (salutogenesis) and finally to a focus on the origins of strength. He identified several authors with a similar theme of focussing on health, as opposed to disease, but highlighted in particular the work of Antonovsky and his concept of a sense of coherence as typical of this paradigm. Antonovsky concluded that the human condition is stressful, and that stressors are ubiquitous in human existence yet not all people succumb to the ever present pathogens in their environment (Strümpfer, 1990).

In an attempt to explain how people stay well, even in the face of adversity, Antonovsky proposed a construct which he called sense of coherence: It is a dispositional orientation that is presumed to engender, sustain, and enhance health, as well as strength at other endpoints. It is a coping resource that is presumed to mitigate life stresses by affecting the overall quality of one's cognitive and emotional appraisal of the stimuli that impact on one. When one's sense of coherence is strong, stimuli from the environment are perceived (a) as comprehensible: making cognitive sense; (b) as being manageable: under the control of both the individual and legitimate others, like a spouse, friends, formal authorities, political leaders, or God; and (c) as being meaningful: motivationally relevant, in the form of welcome challenges that are worth engaging with and investing oneself in (Antonovsky, in Strümpfer, 2000, p. 15).

Strümpfer (1995) presented a series of three different studies undertaken in three work situations of varying demands on 
peoples' strength resources, and concluded that while people are exposed to awful circumstances in their daily work life, what ultimately leads them to survive is fortitude. "To deal with bleak and dismal phenomena, one needs a philosophy of life - and a psychology - concerned with strengths and their origins" (Strümpfer, 1995, p. 87).

If the data from the current research is viewed from the fortigenic paradigm, it is not difficult to find evidence of peoples' strength in facing their daily work. The following statements from participants indicated an underlying positive philosophy:

"Some things change without you even realising it; we forget some of the changes we have been through; change will teach you resilience; it is about choosing to have a positive attitude; despite all the change my job is challenging; I believe that I can make it anywhere; I face things head on; I draw on the strength of my sister who was very strong in the face of illness; if you don't like where you are going, change it; life is hard enough as it is, don't make it worse for yourself; you have to bounce back at a higher level to survive; I was forced to change my way of thinking".

The fortigenic paradigm might possibly provide an explanation of why the results of the study are not as negative as would have been expected. Despite being exposed to constant organisational change, it appears that most the participants adopted elements of a positive outlook. It is important to note that none of the proponents of the salutogenesis or fortigenesis paradigms aim to diminish the severity of the suffering of individuals who are exposed to any stressors. They do aim, however, to understand how and why people are able to survive under difficult circumstances so as to increase the number of people who do (Strümpfer, 1995).

The study highlighted important individual experiences of constant organisational change that may add to an understanding of the impact of change interventions within organisations, and the change management practices that should ideally accompany these.

\section{CONCLUSION}

The findings discussed above should be interpreted with a fair degree of caution. The study was of a preliminary nature and of limited scope, depending on data from only a small number of interviews. More interviews might have yielded richer data that would have provided a better foundation for theory generation. It is also important to note that people who were interviewed were "survivors" of the most recent organisational change; their experiences were probably different from people who did not. Traditional triangulation methods in the form of using various sources of data were also not used in the study, and any future research would benefit from using multiple data gathering techniques. It would also be of interest to consider the impact of specific organisational cultures on the experiences of individuals within an organisational change context. For these reasons future studies could expand this research by conducting more interviews, and conducting more than one interview with each person. Research across different companies and industries would also be revealing.

However, the value of the study is that it has demonstrated that people seem to be more resilient than previously thought. There are indications that despite the cumulative effects of constant change, people are able to transfer their learning in terms of coping with change between different contexts. While the impact of change on individuals may not be negative in the long term, change management practices may be questioned with regard to their ability to bring about sustainable change in organisations. Change can only be sustainable in organisations if employees are committed to the changes, and the absence of long-term negative effects of constant change does not necessarily equal commitment to change. For this reason, change management practices should be further developed to ensure employee commitment in the face of continued organisational change.

\section{REFERENCES}

Armenakis, A.A. \& Bedeian, A.G. (1999). Organisational change: a review of theory and research in the 1990's. Journal of Management, 25 (3), 293-308.

Armstrong, M. \& Murlis, H. (1997). Reward management (3 $3^{\text {rd }}$ ed.). London: Kogan Page.

Applebee, D. (2000). Corporate change. Unpublished paper submitted in partial fulfilment of the requirements of the Executive MBA program. University of Cape Town.

Arthur, W.B. (1996). Increasing returns and the new world of business. Harvard Business Review, July - August, 100-109.

Beer, M, \& Eisenstadt, R.A. (1996). Developing an organization capable of implementing strategy and learning. Human Relations, 49 (5), 597-619.

Birkin, M. (1998).Changing corporate culture: combining global competition with local culture. http://pgw.org/vgc/mt/ vhr95504.htm

Bryman, A. (1989). Research methods and organization studies. London: Unwin Hyman.

Burnes, B. (1997). Organizational choice and organizational change. Management Decision, 35 (9/10), 753-760.

Callan, V.J. (1993). Individual and organisational strategies for coping with organizational change. Work \& Stress, 7 (1), 63-75.

Company Annual Report (1998).

Dunphy, D. \& Stace, D. (1993). The strategic management of corporate change. Human Relations, 46 (8), 905-920.

Easterby-Smith, M., Thorpe, R.E., Lowe, A. (1991). Management research: an introduction. London: Sage.

Glaser, B.G. \& Strauss, A.L. (1967). The discovery of grounded theory. Chicago: Aldine.

Hall, D.T. \& Mirvis, P.H. (1995). The new career contract: developing the whole person at midlife and beyond. Journal of Vocational Behaviour, 47, 269-289.

Hamel, G. \& Prahalad, C.K. (1989). Strategic intent. Harvard Business Review, 67, 63-76.

Horwitz, F. (1995). Flexible work practices in South Africa: economic, labour relations and regulatory considerations. Industrial Relations Journal, 26 (4), 257-266.

Horwitz, F.M. \& Franklin, E. (1996). Flexible work practices come to SA. People Dynamics, 14 (9), 12-16.

Hussey, J. \& Hussey, R. (1997). Business research. London: Macmillan Business.

Huuhtanen, P. (1992). Stress and change among bank directors and supervisors. Scandanavian Journal of Work Environment and Health, 18, 121-122.

Isabella, L.A. (1990). Evolving interpretations as a change unfolds: how managers construe key organizational events. Academy of Management Journal, 33 (1), 7-41.

Jex, S.M., Adams, G.A., Elacqua, T.C. \& Lux, D.J. (1997). A comparison of incident based and scale measures of work stressors. Work \& Stress, 11 (3), 229-238.

Kets de Vries, M.F.R. \& Balazs, K. (1997). The downside of downsizing. Human Relations, 50 (1), 11-50.

Kotter, J.P. (1995). Leading change: why transformation efforts fail. Harvard Business Review, March - April, 59-67.

Lascaris, R. \& Lipkin, M. (1993). Revelling in the wild: business lessons out of Africa. Cape Town: Human \& Rossouw.

Leong, C.S., Furnham, A.E. \& Cooper, C.L. (1996). The moderating effect of organizational commitment on the occupational stress outcome relationship. Human Relations, 49 (10), 1345-1363.

Mabaso, J. (1998). From managing diversity to managing reality. People Dynamics, 16 (1), 15-18.

Mack, D.A., Nelson, D.L. \& Quick, J.C. (1998). The stress of organisational change: a dynamic process model. Applied Psychology: An International Review, 47 (2), 219-232. 
Manning, T. (1997). Crafting the corporate conversation. People Dynamics, 15 (11), 50-55.

Marshall, E.M. (1995). Transforming the way we work: the power of a collaborative workplace. New York: Amacom.

Maxwell, J.A. (1996). Qualitative research design: an interactive approach. California: Sage.

McHugh, M. (1997). The stress factor: another item for the change management agenda? Journal of Organizational Change Management, 10 (4), 345-362.

McLagan, P. \& Nel, C. (1996). The shift to participation. People Dynamics, 14 (5), 12-17.

McLagan, P. \& Nel, C. (1997). The age of participation. San Francisco:Berrett-Koehler.

Pandit, N.R. (1996). The Creation of Theory: A recent application of the grounded theory method. The Qualitative Report, 2 (4). http://www.nova.edu/ssss/QR/QR2-4/pandit.html

Pretorius, T.B. (1992). Problem solving appraisal in the association of life stress and depression: A South African study. Psychological Reports, 71, 855-862.

Pretorius, T.B. (1993). Commitment, participation in decisionmaking and social support: direct and moderating effects on the stress-burnout relationship within an educational setting. South African Journal of Psychology, 23 (1), 10-14.

Quick, J.C., Quick, J.D., Nelson, D.L. \& Hurrell, J.J. Jr. (1997). Preventative stress management in organizations. Washington DC: American Psychological Association.

Sarason, I.G. \& Johnson, J.H. (1979). Life stress, organizational stress and job satisfaction. Psychological Reports, 44, 75-79.

Schabracq, M.J., \& Cooper, C.L. (1998). Toward a phenomenological framework for the study of work and organizational stress. Human Relations, 51 (5), 625-648.

Scheck, C.L., Kinicki, A.J., \& Davy, J.A. (1997). Testing the mediating processes between work stressors and subjective well-being. Journal of Vocational Behaviour, 50, 96-123.

Shukla, M. (1997). Competing through knowledge: building a learning organisation. New Delhi: Response Books.

Siegal, W., Church, A.H., Javitch, M., Waclawski, J., Burd, S., Bazigos, M., Yang, T.F., Anderson-Rudolph, K. \& Burke, W.W. (1996). Understanding the management of change: An overview of managers' perspectives and assumptions in the 1990's. Journal of Organizational Change Management, 9 (6), 54-80.
Sifonis, J. (2001). Foreword. In W. Grulke. 10 Lessons from the future. London: Pearson.

Simmons, S. (1996). Flexible working. London: Kogan Page.

Slabbert, J.A., \& de Villiers, A.S. (1998). The South African Organisational Environment (3rd Ed.). Publication source unknown.

Smaling, A. (1989). Münchhausen Objectivity: A BootstrapConception of objectivity as a methodological norm. In W.J. Baker, M.E.Hyland, R. van Hexewijk, S. Terwee (Eds). Recent Trends in Theoretical Psychology Volume II. New York: Springer-Verlag.

Smaling, A. (1992). Objectivity, reliability and validity. In G.J.N. Bruinsma \& M.A. Zwanenburg (Eds). Methodology for management specialists: Trends and methods. Muiderberg: Coutinho.

Sparrius, S.K. (1992). Occupational stressors among ambulance and rescue service workers. South African Journal of Psychology, 22 (2), 87-91.

Strümpfer, D.J.W. (1989). Do white South African managers suffer from exceptional levels of job stress? South African Journal of Psychology, 19 (3), 130-137.

Strümpfer, D.J.W. (1990). Salutogenesis: A new paradigm. South African Journal of Psychology, 20 (4), 265-276.

Strümpfer, D.J.W. (1995). The origins of health and strength: from salutogenesis to fortigenesis. South African Journal of Psychology, 25 (2), 8189.

Strümpfer, D.J.W. (2000). Psychofortology: Review of a new paradigm marching on. Draft unpublished manuscript.

Teke, M. (1997). Empowering the South African Worker. People Dynamics, 15 (10), 22-31.

Terry, D.J. \& Callan, V.J. (1997). Employee adjustment to large scale organisational change. Australian Psychologist, 32 (3), 203-210.

Veldsman, T.H. (1997). Architect or victim of the future? In search of an appropriate change management logic for turbulent times. Edited manuscript of a paper presented at the Annual Convention of the Institute of People Management on 12-14 September 1994 at Sun City, South Africa.

Winslow, C.D. \& Brammer, W.L. (1994). Future work. New York: The Free Press. 